YAK 347.77:(007:004.73)

DOI https://doi.org/10.32837/chc.v0i35.189

Калітенко Оксана Михайлівна, канАиАат юриАичних наук, Аоцент, Аоцент кафеАри цивільного права Національного університету "ОАеська юридична академія"

\title{
ПРАВО НА ЗАБУТТЯ: ЗДОБУТОК ЄВРОПЕЙСЬКИЙ ЧИ ГЛОБАЛЬНИЙ?
}

Постановка проблеми. Реалії сучасного цифрового суспільства яскраво свідчать про необхідність оновлення і трансформації системи особистих немайнових прав фізичної особи. Безспірним $€$ той факт, що значна частина окремих АюАСьких і суспільних віАНосин СьОГоАні вихоАить із формату офф-лайн і переходить у формат он-лайн. При цьому якщо правові механізми реалізації й захисту особистих немайнових прав фізичної особи в реальному житті можна вважати Аостатньо розробленими, то аналогічні правові інструменти Аля інтернет-віАносин перебувають на стадії формування, активного обговорення й нескінченних Аискусій [1, с. 96-101; 2, с. $102-$ 105; 3, с. 112-115]. Значна кількість наукових АосліАжень як суто теоретичного, так і практичного характеру останнім часом присвячується питанням захисту персональних даних фізичної особи, які внаслілок інтернет-активізації суспільства стали максимально Аоступними й недостатньо АосліАженими [4; 5]. У світлі набрання чинності GDPR розгляАається необхіАність захисту також і “нових" немайнових прав фізичної особи, зокрема права на забуття.

Стан АосліАження теми. Варто зазначити, що натепер окремих цілісних наукових АосліАжень права фізичної особи на забуття фактично немає. Можливо, це пояснюється новизною цього права та практикою реалізації, яка тільки формується. ВіАсутність вітчизняних АосліАжень із цього приводу, скоріше за все, пояснюється територіальністю застосування цього права (що обмежується територією ЄС). ОАнак у світлі рекодифікації цивільного законодавства України, початок якої проголошений у липні 2019 року [6], варто звернути увагу на означене право з метою можливої подальшої імплементації норм, що його регулюють в національне законодавство.

Мета стапті - Аослідити поняття, етапи формування й сучасні аспекти реалізації й захисту права фізичної особи на забуття.

ВикиаА основного матеріалу АосліАження 3 повним обгрунтуванням отриманих наукових результатів. ПіАґрунтям виникнення й подальшого розвитку права на забуття традиційно прийнято вважати рішення Суду СправеАливості Європейського Союзу (2014 рік) у справі "Google Spain SL, Google Inc. v Agencia Española de Protecciónde Datos, Mario Costeja González" [7]. Згідно з означеним рішенням, Суд Європейського Союзу зобов'язав компанію Google видалити з пошукової системи інформацію стосовно примусового продажу нерухомості громадянина Іспанії Mario Costeja González у зв'язку з його заборгованістю із соціального забезпечення, що відбувся десять років тому.

Аискусійність та основна "проблематичність" означеного права виражається в тому, що воно знаходиться на межі Авох особистих немайнових прав фізичної особи: з одного боку, це право на інформацію (що передбачає вільний доступ до неї та її віАкритість і віАсутність будь-якої цензури), а з іншого - право фізичної особи на приватність (повагу до приватного й сімейного життя та право на захист персональних Ааних, що закріплені в ст. ст. 7-8 Хартії Європейського Союзу про основні права) [8].

З 2014 року право на забуття (англ. right to before gotten) фактично почало розвиватися і стало предметом численних Аискусій у багатьох Аержавах. На сучасному етапі ВікіпеАія визначає його як право АюАини, що Аозволяє їй вимагати 
за певних умов видалення своїх особистих Ааних із загального Аоступу через пошукові системи, тобто посилань на ті дані, які, на ії Аумку, можуть завдати (або вже завАають) їй шкоди. Це стосується застарілих, недоречних, неповних, неточних або наАлишкових Ааних чи інформації, законні підстави Аля зберігання якої зникли з плином часу [9].

Варто звернути увагу на те, що, розглядаючи справу іспанця, Суд Європейського Союзу проаналізував питання про баланс приватних і суспільних інтересів і визнав, що право на забуття може надаватися громадянину (фізичній особі) тільки в тому випаАку, якщо відсутня зацікавленість широкої спільноти в інформації про конкретну особу, а також якщо громадянин не відіграє особливу, значну й важливу суспільну роль.

Програвши у справі 3 іспанцем, компанія Google 3 метою виконання рішення Суду Європейського Союзу, а також піА примусом європейських регуляторів зАійснила необхідні заходи з метою мінімізації судових позовів: запустила на власному веб-сайті спеціальну онлайн-форму заявки, за Аопомогою якої користувач може звернутися Ао пошукового сервісу із запитом про видалення приватної інформації про себе з пошукової системи. При цьому, аналізуючи випаАки задоволення таких запитів, можна зробити узагальнений висновок про необхідні (сприйняті Google) підстави Аля видалення інформації. Як правило, такими підставами називають:

1. Аавність обставин, що називаються в інформації (якщо брати за основу справу іспанця - не менше ніж 10 років). Хоча, наприклаА, за проектом російського закону щодо права на забуття, така Аавність встановлюється в три роки).

2. Недостовірність або неактуальність інформації про особу. Тобто розміщена в інтернеті інформація або не відповідає Аійсності, або хоча й відповідає Аійсності, але $€$ не важливою на сучасному етапі.

3. Суспільна зацікавленість в інформації про особу. Ця підстава $€$ найбільш складною Аля визначення. Вона випливає з того, яку роль у суспільному житті відіграє та чи інша ^юдина й, відповідно, яке місце вона посідає в соціумі. Так, консультативна рала Google зазначила, що в контексті права на забуття можна виділити три групи суб'єктів, які можуть звернутися з вимогою про видалення інформації з пошукової системи. ОАнак вирішення питання обов'язково буде залежати віА суспільної ролі, яку відіграє та чи інша ^юдина, а саме:
1. Суб'єкти, що не відіграють помітної ролі в суспільному житті (соціально та суспільно неактивні або малоактивні). А^я таких ^юдей видалення інформації може бути цілком виправданим, бо не порушує інтересів (зацікавленості) суспільства і громадськості загалом.

2. Особи, що мають чітко визначену соціальну й суспільну роль, наприклаА, політичні Аіячі, керівники, релігійні лідери, зірки спорту та шоу-бізнесу. У силу їхньої публічності й вагомої суспільної ролі Аоступ Ао інформації про них не має бути обмежений. Інтереси громади та суспільства в такому випадку переважають наА інтересами однієї приватної особи. Коли ^юдина обирає Аля себе шлях публічності, вона повинна усвідомлювати зацікавленість громаАськості в будь-якій інформації щодо неї.

3. Особи, що відіграють специфічну або обмежену роль у громадському та суспільному житті. НаприклаА, Аиректор школи, Аержавний службовець, тощо. Видалення Ааних із мережі про таких осіб буде залежати віА змісту самої інформації та ії значення Аля суспільства.

За Ааними Google (на 2018 рік), із моменту появи вказаного рішення компанія отримала 860141 запит на видалення інформації з пошукової системи. Вона задовольнила 45\% із них і виламила 3404922 посилання в інтернеті. Звертає на себе увагу той факт, що кількість запитів на видамення інформації щоденно зростає й, віАповіАно, постає питання про компетенцію пошукового сервісу щодо оцінювання розміщеної інформації та ії видалення. Можливо, цими питаннями повинна займатися окрема правова структура, що буде перевіряти підстави й установ^ювати факт порушення права на забуття.

Натепер практика реалізації права на забуття набирає глобального світового поширення, що призвело Ао голосних та емоційних Аискусій між користувачами інтернету й пошуковими системами (Google, Яндекс тощо), які зводяться фактично Ао принципового вирішення питання про обов'язок чи право видаляти інформацію стосовно ^юдини за їі запитом і за наявності означених вище вимог.

Крім того, приводом Аля Аискусій (і в тому числі Аля судових спорів) стало також питання територіальності поширення право на забуття. Так, із моменту своєї появи означене право визнавалося таким, що Аіє на території Європейського Союзу, тому фактично компанія Google не видаляла інформацію зі світової мережі, а лише встановлювала геолокаційні обмеження (тобто 


\section{2 回回回回回回回回回回回回回回回回回回回回 Випуск 35}

інформація була недоступною з IP-адрес, що знаходилися на території ЄС). ОАнак, як зазначали спеціалісти, за межами ЄС або за допомогою VPN з такою інформацією можна було ознайомитися. У 2018 році Франція звернулася в Суд ЄС із позовом про видалення інформації зі світової мережі (а не тільки з пошукових систем країн ЄС). Однак у відповідь компанія Google зазначила, що видалення інформації зі світової мережі варто вважати своєрідною цензурою інтернету, а інтернет створений саме Аля поширення інформації й обміну нею, а компанія Google - це пошуковик, а не орган світової цензури.

24.09.2019 Google виграв судовий процес із Францією перед Судом ЄC (TSUE) в ^юксембурзі щодо права бути забутим. Згідно з рішенням Суду, це право поширюється тільки на версію пошукової системи в державах-членах ЄС, але не за межами ЄС. Суд також ухвалив, що ця справа не $є$ універсальною, а право на забуття - абсо^ютним: рішення в аналогічних справах виноситимуться на основі конкретних обставин, щоб вик^ючити їх протиріччя 3 фундаментальними правами ^юАини (свободи слова і Аруку): принцип а case-by-caseassessment [10].

у сучасних умовах право на забуття можуть реалізовувати ^юАи (фізичні особи), що живуть на території Європейського Союзу. ГромаАянин США, що живе в Європі, може скористатися європейською формою запиту на видалення. А ось європеєць, що проживає за межами ЄС і має IP-адресу іншої країни, - ні.

Аналізуючи процес виникнення, формування та розвитку права на забуття на Аумку, в черговий раз Аоходять питання щодо спроможності права врегулювати інтернет-віАносини в класичному розумінні правового регулювання. Періодично складається враження, що поки країни приймають законодавчі акти з питань регулювання й захисту тих чи інших інтернет-відносин, спеціалісти створюють способи та знаходять методи, як саме таке правове регулювання можна обійти. Яскравим прикладом такої ситуації можна вважати застосування сервісу VPN, коли виникає потреба обійти встановлені державою заборони. Аійсно, більшість законослухняних громадян із високим рівнем правосвідомості виконує встановлені заборони. А^е, з іншого боку, як свідчать практики, у разі необхідності отримати інформацію навіть із заборонених законом інтернет-Ажерел можливо та й не занадто склално. Саме тому на сучасному етапі увага має звертатися не тільки на створення й удосконалення правових механізмів захисту інтернет-віАносин, а й насампереА, як ніколи раніше, на підвищення рівня правосвіАомості та усвідомлену інтернет-активність фізичних осіб. У сучасних умовах фраза "все таємне колись стає явним" працює стовідсотково. Саме тому фізична особа має поводитися в суспільстві так, щоб у подальшому не треба було звертатися Ао пошукових систем із вимогами про виАалення інформації.

На шпальтах інтернет-видань [11] існує також точка зору, що право на забуття - зразок класичних правових способів приховати інформацію. Кожна ^юдина має право на помилку (і не один раз за життя). Такі помилки можна виправити, але їх не можна викреслити із життя мюАини. Можливо, не варто в черговий раз переписувати біографію, а Аоцільно залишити їі такою, як вона є. І тим самим позбавити пошукові системи непритаманної їм функції оцінювати й видаляти або блокувати інформацію про ^юдину.

В Україні ще не розглянуто жодного спору, пов'язаного з правом на забуття. Утім поява такої категорії справ і у вітчизняному правовому полі видається цілком реальною, оскільки українці, як і будь-хто, можуть подавати запити про видалення своїх персональних Ааних із пошукової системи Ао відповіАного оператора. А в разі віАмови ніщо не перешкоАжає звернутися Ао суду.

Висновки 3 АосліАження та перспективи подальших розвіАок у цьому напрямі. Подальше впровадження в Україні європейської моделі права на забуття пов'язане з відносинами інтеграції та асоціації України та ЄС, застосуванням судової практики ЄСП^ у національному судочинстві, а також із майбутньою законотворчою Аіяльністю (зокрема з рекодифікацією цивільного законодавства України).

Усе вищевикладене свідчить про те, що на сучасному етапі розвитку мюдства право на забуття, безспірно, є європейським зАобутком. А от чи стане воно здобутком глобальним, покаже час і практика, хоча запит на масштабування цього права спостерігається вже сьогодні.

\section{NITEPATYPA:}

1. Х Харитонов С.О., Харитонова О.І., Спасова К.І. Формування Одеської школи ІТ-права. Часопис ичивілістики. 2017. № 27. C. 96-101

2. Голубева Н.Ю. Информационные технологии и юридические услуги. Часопис ициілістики. 2017. № 27. С. $102-105$.

3. Омельчук О.С. Вектори та форми впливу ІТ-права на суспільну свідомість. Часопис циивілістики. 2017. № 27. С. 112-115. 
4. Сарвас М. Життя після GDPR. URL: http://yur-gazeta.com/publications/practice/inshe/zhittya-pislya-gdpr.html.

5. Защита персональных данных в процессе использования таргетированной рекламы и прямого маркетинга: национальные и европейские требования. URL: https://egalitgroup.com/ru/zashchita-personalnykh-dannykh-pri-ispolzovanii-reklami/.

6. Про утворення робочої групи щодо рекодифікації (оновлення) цивільного законодавства України : Постанова Кабінету Міністрів України від 17.07.2019 № 650. URL: https://zakon.rada.gov.ua/laws/show/650-2019-\%D0\%BF.

7. GoogleSpainv. AEPD and Mario Costeja González. URL: http://curia.europa.eu/juris/document/document_print.jsf?doclang= EN\&docid $=152065$.

8. Х Хартия Европейского Союза об основных правах (Страсбург, 12 декабря 2007 г.) (2016/C 202/02). CПC Гарант. Forgotten. URL: https://static.googleusercontent.com/media/archive.google.com/ru//advisorycouncil/advisement/advisory-report.pdf.

9. Право на забуття. Вікіnедія. URL: https://uk.wikipedia.org/wiki/\%D0\%9F\%D1\%80\%D0\%B0\%D0\%B2\%D0\%BE_\%D0\%BD\% D0\%B0_\%D0\%B7\%D0\%B0\%D0\%B1\%D1\%83\%D1\%82\%D1\%82\%D1\%8F.

10. Андрощук Г. Суд ЄC: Google виграв спір щодо права на забуття. URL: http://yur-gazeta.com/publications/practice/zahistintelektualnoyi-vlasnosti-avtorske-pravo/sud-es-google-vigrav-spir-shchodo-prava-na-zabuttya.html.

11. Гордієнко Т. Право на забуття: що це таке і чому про нього варто знати? URL: https://ms.detector.media/trends/1411978127/ pravo_na_zabuttya_scho_tse_take_y_chomu_pro_nogo_varto_znati/.

\section{Калітенко Оксана Михайлівна}

\section{ПРАВО НА ЗАБУТТЯ: ЗАОБУТОК ЄВРОПЕЙСЬКИЙ ЧИ ГЛОБАЛЬНИЙ?}

Стаття присвячена дослідженню поняття, етапів формування та сучасних аспектів реалізації й захисту права фізичної особи на забуття.

У статті акцентується увага на необхідності оновлення правового регулювання окремих особистих немайнових прав фізичної особи, що виникають і реалізуються в мережі інтернет і невіА'ємно пов'язані з розвитком сучасних технологій та інформаційних сервісів. Таке оновлення пов'язується також із рекодифікацією цивільного законодавства України, яка має на меті створення новітніх правових конструкцій і механізмів. Наголошується на необхідності вАосконалення сучасних напрямів захисту персональних Ааних, передбачених GDPR, у тому числі через упроваАження в сучасну систему цивільного законодавства України права на забуття. Надається визначення права на забуття, характеризується його зміст та окремі особливості застосування. Робиться висновок про європейські та світові перспективи розвитку права на забуття й можливі проблеми його впровадження та реалізації. Також порушується питання про можливість, Аоцільність і віАповідність звичного формату правового регулювання суспільних віАносин Аля віАносин, що виникають у мережі інтернет, і робиться висновок про необхіАність перегляАу деяких моделей правового регулювання з урахуванням сучасних тенденцій розвитку законодавства і права.

Окрема увага приділяється напрямам розвитку права на забуття в країнах-членах ЄС. Розгляається можливість імплементації права на забуття у вітчизняне законодавство України у світлі рекодифікації цивільного законодавства. Характеризуються окремі рішення європейських судів з питань захисту права на забуття й наголошується на необхідності детального досліАження таких рішень $з$ метою формування практики правозастосування права на забуття в сучасному суспільстві.

Унаслідок проведеного досліАження авторкою робиться висновок про те, що вже сьогодні право на забуття можна вважати європейським здобутком. ОАнак чи стане це право зАобутком глобальним, мають показати час і практика.

Киючові слова: право на забуття, фізична особа, інформація, пошукові системи, суд ЄС.

\section{Калитенко Оксана Михайловна}

\section{ПРАВО НА ЗАБВЕНИЕ: ПРИОБРЕТЕНИЕ ЕВРОПЕЙСКОЕ ИАИ ГАОБААЬНОЕ?}

Статья посвящена исследованию понятия, этапов формирования и современных аспектов реализации и защиты права физического мица на забвение.

В статье акцентируется внимание на необходимости обновления правового регулирования отдельных мичных неимущественных прав физического мица, которые возникают и реализуются в мировой сети интернет и неразрывно связаны с развитием современных технологий и электронных информационных сервисов.

Такая необходимость обновления правового регулирования кичных неимущественных прав физических лиц связывается также с рекодификацией гражданского законодательства Украины, целью которой является создание новейших правовых конструкций и механизмов. Акцентируется внимание на необходимости усовершенствования современных направлений защиты персональных Аанных физических лиц, предусмотренных GDPR, в том числе посредством введения в современную систему гражданского законодательства Украины права на забвение. Также обосновывается необходимость срочного приведения национального законодательства по вопросам защиты персональных данных в соответствие с илеями и направлениями, предусмотренными в GDPR.

В ходе исследования Аается определение права на забвение, характеризуется его содержание и отдельные особенности правоприменения. Аелается вывод относительно европейских и мировых перспектив развития права на забвение и возможных проблем его введения и реализации. Также поднимается вопрос о возможности, целесообразности и соответствия традиционного формата правового регулирования общественных отношений Аля отношений, которые возникают в сети интернет. Аелается вывод о необходимости пересмотра некоторых 
моделей правового регулирования с учетом современных тенденций развития законоАательства и права. ПреАмагается обратить внимание на европейские методы и способы частноправового регулирования общественных отношений и использовать их в процессе рекодификации гражАанского законодательства Украины.

ОтАельное внимания уделяется формирующимся направлениям развития права на забвение в странах-членах ЕС. Рассматривается возможность имплементации конструкции права на забвение в национальное гражАанское законодательство в свете рекодификации гражАанского кодекса Украины. Характеризуются отАельные решения европейских судов по вопросам защиты права на забвение и акцентируется внимание на необходимости Аетального изучения таких решений с целью формирования практики правоприменения права на забвение в современном обществе. Обращается внимание на специфику реализации и защиты права на забвение, которая заключается в объеАинении оффлайн и онлайн общественных отношений.

В результате проведенного исследования Аелается вывоА, что уже сегодня право на забвение является приобретением европейским. Но станет ли это право мировым приобретением, покажут время и практика.

Кюючевые слова: право на забвение, физическое лицо, информация, поисковые системы, суд ЕС.

\section{Kalitenko Oksana}

\section{RIGHT TO BE FORGOTTEN: EUROPEAN OR GLOBAL ACHIEVEMENT?}

The article is devoted to the study of the concept, stages of formation and modern aspects of the implementation and protection of the right to be forgotten.

The article focuses on the need to update the legal regulation of personal non-property rights of an individual that arise and are realized on the global Internet, which are inextricably linked with the development of modern technologies and electronic information services.

This need to update the legal regulation of personal non-property rights of individuals is also associated with the recodification of the civil legislation of Ukraine, the purpose of which is to create the latest legal structures and mechanisms. The focus is on the need to improve modern areas of personal data protection provided by the GDPR, also through the introduction of the right to be forgotten into the modern system of civil legislation of Ukraine. The need to urgently bring national legislation on the protection of personal data into line with the ideas and directions provided for in the GDPR is also indicated.

The study defines the right to be forgotten, characterizes its content and certain features of law enforcement. The conclusion is drawn about the European and world prospects for the development of the right to be forgotten and the possible problems of its introduction and implementation. The article also raises the question of the possibility, feasibility and relevance of the traditional format of legal regulation for relations that arise on the Internet. The conclusion is drawn about the need to review some models of legal regulation taking into account current trends in the development of legislation and law. It is proposed to pay attention to European methods and methods of private regulation of public relations and use them in the process of recodification of civil legislation of Ukraine.

As a result of the study, it is concluded that today the right to be forgotten is a European achievement. But whether this right will become a world achievement only time and practice will show.

Key words: right to be forgotten, individual, information, search engines, European Court. 